\title{
Novel Mixed Ligand Complexes of Alkaline Earth Metal Cations Containing Nicotinamide and Diphenic Acid. Synthesis and Structural Properties
}

\author{
Omer Yurdakul \\ Hitit University: T C Hitit Universitesi \\ Dursun Ali Köse ( $\sim$ dalikose@hitit.edu.tr) \\ Hitit University https://orcid.org/0000-0003-4767-6799 \\ Zarife Sibel Şahin \\ Sinop University: Sinop Universitesi \\ Onur Şahin \\ Sinop University: Sinop Universitesi
}

\section{Research Article}

Keywords: diphenic acid, nicotinamide, mixed ligand complex, crystal structure, thermal analysis

Posted Date: May 28th, 2021

DOI: https://doi.org/10.21203/rs.3.rs-564081/v1

License: (c) (i) This work is licensed under a Creative Commons Attribution 4.0 International License. Read Full License 


\section{Abstract}

Mixed-ligand coordination compounds containing neutral nicotinamide and monoanionic diphenate organic molecules of alkaline earth metal cations, $\mathrm{Mg}^{2+}(\mathrm{I}), \mathrm{Ca}^{2+}(\mathrm{II}), \mathrm{Sr}^{2+}(\mathrm{III})$ and $\mathrm{Ba}^{2+}(\mathrm{IV})$ were synthesised. Chemical composition analysis, single crystal XRD, spectroscopic and thermal analysis methods were used to determine the structural properties of the compounds obtained. According to the data obtained from single-crystal XRD analysis of the Mg ${ }^{2+}$ complex, the coordination environment of the metal cation was surrounded by four aqua and two nicotinamide ligands to form a distorted octahedral geometry. The charge balance of the complex sphere was provided by two diphenate ligands placed mono-anionically outside the coordination sphere. The structure is a salt type complex. Since crystals suitable for single crystal structure analysis of other metal cations complexes (II, III and IV) could not be formed, the structural properties were tried to be explained by chemical composition analysis, spectroscopic and thermal analysis methods. Accordingly, it is thought that the coordination circles of metal cations are octal and all ligands (two aqua, two neutral nicotinamide and two monoanionic-double-toothed diphenate) coordinate with the metal in the coordination sphere. The geometries of the complexes are thought to be of distorted cubic structure.

\section{Introduction}

The crystalline coordination polymer (Metal-Organic Frameworks, MOFs or Metal-organic coordination networks, MOCNs) solids are widely used in many applications such as gas storage [1-3], ion (cation or anion) Exchange [4-6], explosive detection [7], heterogeneous catalysis [8, 9], small molecule separation [10], luminescence [11], second harmonic generation [12], magnetism [13], chirality [14], spin-transition [15] and non-linear optics [16].

The coordination polymers are metal-ligand compounds that extend "infinitely" into one (1D), two (2D) or three (3D) dimensions via more or less covalent metal-ligand bonding [17]. Metal-organic polymers or supramolecular structures, now called MOFs, were mentioned in 1965. In this study, divalent and tetravalent aromatic carboxylic acids (1,5-Dihydroxynaphthalene-2,6-dicarboxylic acid, pyromellitic acid and 2,3,6,7-naphthalenetetracarboxylic acid) were used to form frameworks with zinc, nickel, iron, aluminium, thorium and uranium [18]. In adsorptive separation, porous solid materials such as zeolites and activated carbons are generally used as adsorbents. Metal-Organic Frameworks (MOFs) are adsorbents with special structures and adjustable properties for efficient, energy-saving and environmentally friendly applications and gas separation processes [19].

Until 1985, few examples of specified crystal structures of coordination polymers had been reported. Studies on coordination polymers have gained momentum towards to 1990s [20-27]. This is mainly due to the discovery that coordination polymers are able to obtain frames with much greater porosity than crystal zeolites [28-34]. In addition to porosity, the properties of coordination polymers can be adjusted by choice of metal and organic species, which can be attributed to the interest in this field. Research shows that the coordination polymers synthesised by transition metal-ligand (M-0) are the major type compared to those of transition metal-ligand $(\mathrm{M}-\mathrm{N})$. In most coordination polymers, either O-atoms of anions (carboxylates, nitrates, sulfates, phosphates, phenolates) and / or N-atoms of cyanates, cyanides, amines, pyridines form coordination bonds with transition metal atoms. In about $53 \%$ of the transition metal- $\mathrm{O}$ type, the $\mathrm{O}$-atom belongs to carboxylates groups whereas in about $40 \%$ of the transition metal- $\mathrm{N}$ type the $\mathrm{N}$-atom belongs to pyridine groups. These statistics show the significance of carboxylate and pyridine component in synthesising coordination polymers [13].

Diphenic acid (2,2'dibenzoic acid, biphenyl-2,2'-dicarboxylic acid) is an organic compound that exhibits atropisomerism and forms various coordination polymers [35]. Diphenate ligand (divalent aromatic carboxylate) has been an effective and impressive option for the design and construction of coordination polymers partially owing to its ability to seize various twisted and locked structures. Diphenate ligand allows flexible conformations around its central $s p^{2}-s p^{2}$ sigma bond in reply to specific supramolecular conditions during self-assembly, which is not feasible in mostly employed mono-aromatic ligands [36-43]. Studies have also been carried out on the synthesis and structural properties of the transition metal cations of the diphenate ligand and complex compounds with both salt type (where the diphenate ligand is the counter ion) and polymeric mixed ligands (with nicotinamide, $N, N$ diethylnicotinamide and 1,10-phenanthroline) [3,44].

\section{Experimental}

\subsection{Material and instrumentation}

The chemicals (acetate salts of alkaline earth metal salts, diphenic acid (diphen) and nicotinamide (na)) of synthesis were supplied from Sigma-Aldrich and used without purification. Elemental analysis $(\mathrm{C}, \mathrm{H}, \mathrm{N})$ were carried out with LECO, CHNS-932 instrument by standard methods. FTIR spectra were recorded in the $4000-400 \mathrm{~cm}^{-1}$ region with a Perkin Elmer Spectrum One FTIR spectrophotometer using KBr pellets. Thermal analyses (TGA, DTA) were performed by the Shimadzu DTG-60H system, in dynamic nitrogen atmosphere $(100 \mathrm{~mL} / \mathrm{min})$ at a heating rate of $10{ }^{\circ} \mathrm{C} / \mathrm{min}$, in platinum crucibles as sample vessel, using a- $\mathrm{Al}_{2} \mathrm{O}_{3}$ as reference.

\subsection{Synthesis of alkaline earth metal cation complexes}

For the synthesis of complexes with mixed ligands containing diphenic acid/nicotinamide molecules, first, diphenic acid was converted into mono-anionic salt form with sodium bicarbonate (Eq. 1) 


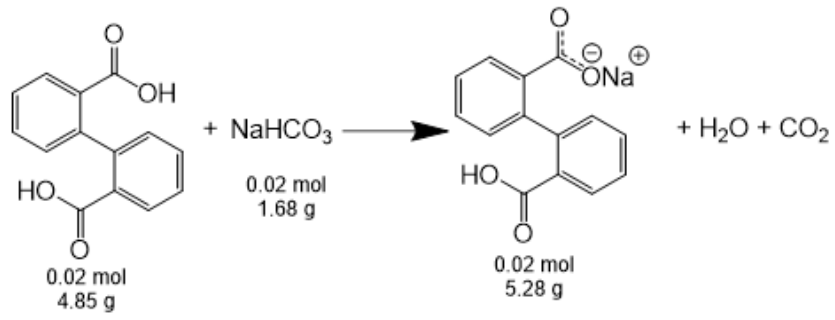

Eq.1

To $0.02 \mathrm{~mol}(5.28 \mathrm{~g})$ of sodium diphenate solution, $0.02 \mathrm{~mol}(2.44 \mathrm{~g})$ of nicotinamide solution and $0.01 \mathrm{~mol}(4.85 \mathrm{~g})$ of acetate salts of corresponding alkaline earth metals $\left(\mathrm{Mg}^{2+}: 2.15 \mathrm{~g}, \mathrm{Ca}^{2+}: 1.76 \mathrm{~g}, \mathrm{Sr}^{2+}: 2.06 \mathrm{~g}\right.$ and $\left.\mathrm{Ba}^{2+}: 2.55 \mathrm{~g}\right)$ in solid form were added sequentially (Eq. 2). The total solutions obtained were mixed on a magnetic stirrer for 3 hours. Then, each of the solutions taken to the reflux system was kept for 24 hours at $65-70{ }^{\circ} \mathrm{C}$ by stirring.

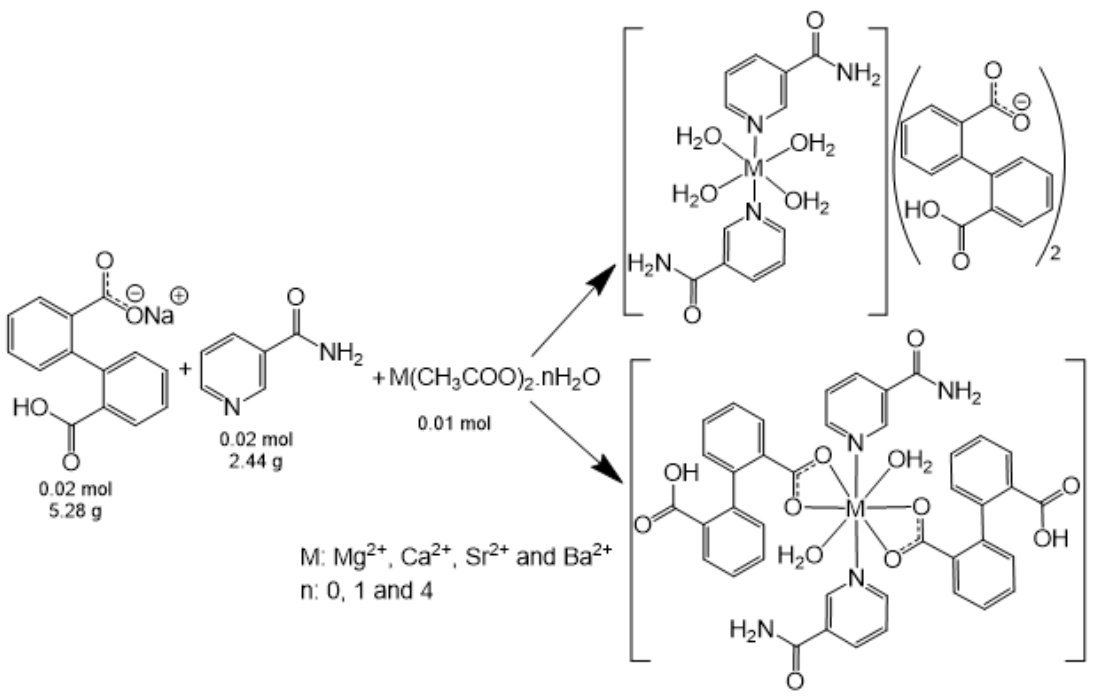

Eq. 2

Then, the beakers of the solutions were sealed with parafilm and crystallised at room temperature within approximately 15-20 days. Only Mg(II) metal cation complex could be obtained from the obtained crystals in accordance with single crystal structure analysis studies. Structural properties of other complexes were examined by spectroscopic and thermal analysis methods.

\subsection{X-ray diffraction analysis}

Suitable crystal of 1 was selected for data collection which was performed on a D8-QUEST diffractometer equipped with graphite-monochromatic Mo-K $\mathrm{a}_{\mathrm{a}}$ radiation at $296 \mathrm{~K}$. The structure was solved by direct methods using SHELXS-2013 [45] and refined by full-matrix least-squares methods on $\mathrm{F}^{2}$ using SHELXL-2013 [46]. The following procedures were implemented in our analysis: data collection: Bruker APEX2 [47]; a program used for molecular graphics were as follow: MERCURY programs [48]; software used to prepare material for publication: WinGX [49]. Details of data collection and crystal structure determinations are given in Table 4. Crystallographic data for the structure reported in this paper have been deposited in the Cambridge Crystallographic Data Center with CCDC number 2035106.

\section{Results And Discussion}

\subsection{Elemental Analysis}

It has been determined that the experimental and theoretical percentage composition of the complex compounds whose chemical compositions are determined by the elemental analysis method are compatible. The chemical composition analysis results and the closed molecule formulas for the complexes based on these results are given in Table 1 . 
Table 1

Elemental analysis data of alkaline earth metal cation complexes.

\begin{tabular}{|c|c|c|c|c|c|c|c|}
\hline \multirow[t]{2}{*}{ Complexes } & \multirow[t]{2}{*}{ M.W. $(\mathrm{g} / \mathrm{mol})$} & \multirow[t]{2}{*}{$\begin{array}{l}\text { Yield } \\
\text { (\%) }\end{array}$} & \multicolumn{3}{|c|}{$\begin{array}{l}\text { Chemical Anal. (\%) } \\
\text { Exp. (Theo.) }\end{array}$} & \multirow[t]{2}{*}{ Colour } & \multirow[t]{2}{*}{ Decomp. Temp. $\left({ }^{\circ} \mathrm{C}\right)$} \\
\hline & & & C & $\mathrm{H}$ & $\mathbf{N}$ & & \\
\hline $\begin{array}{l}{\left[\mathrm{Mg}\left(\mathrm{C}_{6} \mathrm{H}_{6} \mathrm{~N}_{2} \mathrm{O}\right)_{2}\left(\mathrm{H}_{2} \mathrm{O}\right)_{4}\right] \cdot 2\left(\mathrm{C}_{14} \mathrm{H}_{9} \mathrm{O}_{4}\right)} \\
\mathrm{C}_{40} \mathrm{H}_{38} \mathrm{MgN}_{4} \mathrm{O}_{14}\end{array}$ & 823.06 & 85 & $\begin{array}{l}58.13 \\
(58.37)\end{array}$ & $\begin{array}{l}3.98 \\
(4.65)\end{array}$ & $\begin{array}{l}6.87 \\
(6.81)\end{array}$ & bright brown & 135 \\
\hline $\begin{array}{l}{\left[\mathrm{Ca}\left(\mathrm{C}_{6} \mathrm{H}_{6} \mathrm{~N}_{2} \mathrm{O}\right)_{2}\left(\mathrm{C}_{14} \mathrm{H}_{9} \mathrm{O}_{4}\right)_{2}\left(\mathrm{H}_{2} \mathrm{O}\right)_{2}\right]} \\
\mathrm{C}_{40} \mathrm{H}_{34} \mathrm{CaN}_{4} \mathrm{O}_{2}\end{array}$ & 802.81 & 67 & $\begin{array}{l}60.03 \\
(59.85)\end{array}$ & $\begin{array}{l}4.61 \\
(4.27)\end{array}$ & $\begin{array}{l}6.89 \\
(6.98)\end{array}$ & cream & 114 \\
\hline $\begin{array}{l}{\left[\mathrm{Sr}\left(\mathrm{C}_{6} \mathrm{H}_{6} \mathrm{~N}_{2} \mathrm{O}\right)_{2}\left(\mathrm{C}_{14} \mathrm{H}_{9} \mathrm{O}_{4}\right)_{2}\left(\mathrm{H}_{2} \mathrm{O}\right)_{2}\right]} \\
\mathrm{C}_{40} \mathrm{H}_{34} \mathrm{~N}_{4} \mathrm{O}_{2} \mathrm{Sr}\end{array}$ & 850.35 & 91 & $\begin{array}{l}56.22 \\
(56.50)\end{array}$ & $\begin{array}{l}3.85 \\
(4.03)\end{array}$ & $\begin{array}{l}6.53 \\
(6.59)\end{array}$ & light brown & 180 \\
\hline $\begin{array}{l}{\left[\mathrm{Ba}\left(\mathrm{C}_{6} \mathrm{H}_{6} \mathrm{~N}_{2} \mathrm{O}\right)_{2}\left(\mathrm{C}_{14} \mathrm{H}_{9} \mathrm{O}_{4}\right)_{2}\left(\mathrm{H}_{2} \mathrm{O}\right)_{2}\right]} \\
\mathrm{C}_{40} \mathrm{H}_{34} \mathrm{BaN}_{4} \mathrm{O}_{2}\end{array}$ & 900.06 & 86 & $\begin{array}{l}52.93 \\
(53.38)\end{array}$ & $\begin{array}{l}4.12 \\
(3.81)\end{array}$ & $\begin{array}{l}6.25 \\
(6.22)\end{array}$ & brown & 162 \\
\hline
\end{tabular}

\subsection{Infrared spectra}

Infrared spectra showing the binding properties of mixed ligand complexes of alkaline earth metal cations containing diphenate/nicotinamide molecules are given in Fig. 3 and important peaks are given in Table 3. The - $\mathrm{OH}$ stretching bands of the aqua groups, which are the ligand water in the structures of the complexes, were determined in the range of $3650-2650 \mathrm{~cm}^{-1}$. The stretching vibrations of $-\mathrm{N}-\mathrm{H}$, confirming the presence of the nicotinamide ligand, appeared in the range $3402-3195 \mathrm{~cm}^{-1}$. The stretching bands of two different $\mathrm{C}=0$ groups in the structures of the ligands were determined in separate regions. The fact that there is no shift in the $C=0$ stretchings of the amide group $\left(1605-1603 \mathrm{~cm}^{-1}\right)$ indicates that nicotinamide does not perform coordination over this group. The stretching bands belonging to the $\mathrm{C}=0$ group of the diphenate ligand appeared in different regions in the complexes (for the $\mathrm{Mg}^{2+}$ complex $1705 \mathrm{~cm}^{-1}$, for the others $1670-1677 \mathrm{~cm}^{-1}$ ). The peak that appears in the $\mathrm{Mg}^{2+}$ complex coincides with the same region as the sodium diphenate salt, which indicates that the diphenate ligand is not coordinated and anionically located outside the coordination sphere, similar to the sodium salt. In $\mathrm{Ca}^{2+}, \mathrm{Sr}^{2+}$ and $\mathrm{Ba}^{2+}$ complexes, a shift of approximately $30 \mathrm{~cm}^{-1}$ in the $\mathrm{C}=0$ group of the diphenate ligand compared to the sodium diphenate salt was detected, indicating the coordination of the diphenate ligand over the carbonyl group. When the asymmetric and symmetric stretching vibrations of the diphenate ligand belonging to the carboxylate group are examined, it is suggested that the diphenate ligand in the $\mathrm{Mg}^{2+} \mathrm{complex}$ is located outside the coordination sphere as a counter anion for coordination sphere. The difference between asymmetric and symmetric stretching vibrations of the carboxylate group $\Delta v$ (asym-sym) can indicate whether the coordination is monodentate or bidentate. In sodium diphenate salt, this difference of $\Delta v($ asym-sym) was found to be $190 \mathrm{~cm}^{-1}$ similar to the $\mathrm{Mg}^{2+}\left(195 \mathrm{~cm}^{-1}\right)$ complex, while it was $135 \mathrm{~cm}^{-1}$ in the $\mathrm{Ca}^{2+}$ complex, $136 \mathrm{~cm}^{-1}$ in the Sr${ }^{2+} \mathrm{complex}^{2}$ and $133 \mathrm{~cm}^{-1}$ in the $\mathrm{Ba}^{2+}$ complex. This value is below that of the sodium diphenate salt, indicating that the coordination is monoanionic and bidentate [3, 44, $\left.50-52\right]$. The stretching vibrations to $v(\mathrm{M}-\mathrm{N})_{n a}$, which indicate the coordination of ligands in synthesised complexes, were observed in the range of $661-677 \mathrm{~cm}^{-1}$ in all structures. Stress vibrations to $v(\mathrm{M}-0)$, indicating the coordination of the diphenate ligand, were detected in the range of $578-581 \mathrm{~cm}^{-1}$ in all others, except for the $\mathrm{Mg}^{2+}$ complex structure. The stretching vibrations to $v(\mathrm{M}-0)$ of the coordination water present in all structures were determined in the regions $597-$ $536 \mathrm{~cm}^{-1}$. The results obtained are in agreement with similar literature studies of the ligands [3, 44, 50-52]. 
Table 2

Significant FT-IR peaks of alkaline earth metal cation complexes.

\begin{tabular}{|c|c|c|c|c|}
\hline Groups & $\mathrm{Mg}(I I)$ & $\mathrm{Ca}(\mathrm{II})$ & $\operatorname{Sr}(I I)$ & $\mathrm{Ba}(\mathrm{II})$ \\
\hline$v(\mathrm{OH})_{\mathrm{H} 2 \mathrm{O}}$ & $3600-2700$ & $3650-2800$ & $3650-2550$ & $3650-2650$ \\
\hline$v(\mathrm{NH})$ & 3402 & 3399 & 3195 & 3200 \\
\hline$v(\mathrm{CH})$ & 3074 & 3061 & 3058 & 3060 \\
\hline$v(\mathrm{C}=0)_{\text {diphen }}$ & 1705 & 1670 & 1677 & 1676 \\
\hline$v(C=0)_{n a}$ & 1604 & 1603 & 1603 & 1605 \\
\hline$v\left(\mathrm{COO}^{-}\right)_{\text {sym }}$ & 1615 & 1574 & 1578 & 1575 \\
\hline$v\left(\mathrm{COO}^{-}\right)_{\text {asym }}$ & 1422 & 1439 & 1442 & 1442 \\
\hline$\Delta v_{\text {asym-sym }}$ & 195 & 135 & 136 & 133 \\
\hline$\delta(\mathrm{NH})$ & 1538 & 1551 & 1536 & 1536 \\
\hline$\delta(\mathrm{OH})_{\mathrm{H} 2 \mathrm{O}}$ & 1452 & 1401 & 1403 & 1400 \\
\hline$v(\mathrm{C}-0)_{\text {diphen }}$ & 1373 & 1331 & 1345 & 1346 \\
\hline$v_{\mathrm{s}}(\mathrm{C}-\mathrm{N}-\mathrm{C})_{n a}$ & 1319 & 1283 & 1303 & 1299 \\
\hline$v(\mathrm{C}-\mathrm{C})+\delta(\mathrm{CCH})_{r i n g}$ & 1256 & 1253 & 1253 & 1250 \\
\hline$V_{\text {ring }}$ & $1138-764$ & $1156-753$ & $1146-766$ & $1143-763$ \\
\hline$v(\mathrm{CN})_{n a}$ & $950-715$ & $951-717$ & $942-711$ & $945-718$ \\
\hline$v(\mathrm{M}-\mathrm{N})_{n a}$ & 661 & 677 & 666 & 662 \\
\hline$v(\mathrm{M}-\mathrm{O})_{\text {diphen }}$ & - & 581 & 578 & 578 \\
\hline$v(\mathrm{M}-0)_{\text {aqua }}$ & 597 & 544 & 536 & 536 \\
\hline
\end{tabular}

\subsection{Thermal analysis}

Thermal analysis curves of the synthesised coordination compounds recorded under inert nitrogen gas are given in Fig. 4. The data showing the details of the degradation steps and the degradation products of the complexes are also summarised in Table 4 . The $\mathrm{Mg}^{2+}$ complex differs from the other three complexes in terms of its structural features. In the $\mathrm{Mg}^{2+}$ complex structure, the four aqua ligands primarily remove from the structure between $129-220{ }^{\circ} \mathrm{C}$ (theo: $8.75 \%$, exp:8.61\%). The decomposition of organic derivatives begins in the complex structure that is dehydrated. First of all, the diphenate anions located outside the coordination sphere are destroyed and the whole molecule burns away from the structure except the carboxylate groups in the counter ion position anionically (theo:47.92\%, exp:47.11\%). Later, it was determined that the nicotinamide ligands coordinated to the metal cation were burned to break down (theo:29.65\%, exp:28.91\%). \%The powder XRD study showed that MgO remained as the last residue product.

From the thermal analysis results of the other three alkaline metal cations $\left(\mathrm{Ca}^{2+}, \mathrm{Sr}^{2+}\right.$ and $\left.\mathrm{Ba}^{2+}\right)$ complexes, which are thought to have an iso-structure molecule, it is seen that the thermal analysis data of $\mathrm{Ca}^{2+}$ structure is different from the result of $\mathrm{Sr}^{2+}$ and $\mathrm{Ba}^{2+}$. The $\mathrm{Ca}^{2+}$ structure, which has a lower decomposition temperature, begins to degrade with the removal of two aqua ligands in its structure at a temperature range of $108-136{ }^{\circ} \mathrm{C}$ (theo:4.48\%, exp:4.02\%). Afterwards, the degradation of organic ligands continues with the burning of the nicotinamide amide group and the carboxylate group of the diphenic acid that do not participate in the coordination (theo:22.17\%, exp:21.77\%). It is thought that in the temperature range of $308-432{ }^{\circ} \mathrm{C}$, the pyridine rings of nicotinamide ligands and one benzene rings of diphenate ligands are decomposed (theo:38.37\%, exp:37.81\%). It is suggested that diphenate residues, which are the last organic residues in the structure, are burned and broken down in the last decomposition step, which corresponds to the temperature range of $433-841^{\circ} \mathrm{C}$. As the final residue product, it was shown by the powder XRD study that CaO remained in the reaction vessel.

It has been determined that the two water ligands in the coordinated position in the structure have moved away from the two complex structures ( $\mathrm{Sr}^{2+}$ and $\mathrm{Ba}^{2+}$ ) whose thermal analysis curves are very similar (respectively, $171-226^{\circ} \mathrm{C}$ and $140-228{ }^{\circ} \mathrm{C}$ ) (respectively, theo:4.24\%, exp:5.05\%; theo:4.00\%, exp:4.35\%). In the next decay step of both complexes, nicotinamide ligands are thought to burn away from the structure at similar decomposition temperature ranges (theo:28.70\%, exp:29.01\%; theo:27.11\%, exp:26.98\%, respectively). The next degradation step is the temperature zone, which corresponds to the burning of a benzene ring of the diphenate ligand. The final decay steps of the complexes are similar. However, while two separate decay steps were observed in the $\mathrm{Sr}^{2+}$ complex, in the $\mathrm{Ba}^{2+}$ structure, these steps occurred consecutively and could not be fully distinguished from each other (Fig. 4). Detailed data on the degradation steps of the complexes are shown in Table 4. It has been shown by powder XRD studies that both complexes are related metal oxides as final degradation products. 
It has been determined that the theoretical values of the final residue products in all complexes are lower than the experimental values (approximately 1 $1.5 \%)$. The reason for this situation can be shown as the recording of thermal analysis curves in an atmosphere of inert nitrogen gas. Some carbonised carbon residues accumulate on the final metal oxides due to the inability to complete combustion due to insufficient oxygen. For this reason, the colours of all the final residue products were determined as black.

Table 3

Thermal analysis data of alkaline earth metal cation complexes.

\begin{tabular}{|c|c|c|c|c|c|c|c|c|c|c|}
\hline \multirow[t]{2}{*}{ Complex } & & \multirow[t]{2}{*}{$\begin{array}{l}\text { Temperature } \\
\text { Range }\left({ }^{\circ} \mathrm{C}\right)\end{array}$} & \multirow[t]{2}{*}{$\begin{array}{l}\text { DTA }_{\max } \\
\left({ }^{\circ} \mathrm{C}\right)\end{array}$} & \multirow[t]{2}{*}{$\begin{array}{l}\text { Leaving } \\
\text { Group }\end{array}$} & \multicolumn{2}{|c|}{$\begin{array}{l}\text { Mass Loss } \\
\text { (\%) }\end{array}$} & \multicolumn{2}{|c|}{$\begin{array}{l}\text { Remained } \\
\text { Product (\%) }\end{array}$} & \multirow[t]{2}{*}{$\begin{array}{l}\text { Decomp. } \\
\text { Product }\end{array}$} & \multirow[t]{2}{*}{ Colour } \\
\hline & & & & & Exp. & Theor. & Exp. & Theor. & & \\
\hline \multirow{2}{*}{$\begin{array}{l}{\left[\mathrm{Mg}\left(\mathrm{C}_{6} \mathrm{H}_{6} \mathrm{~N}_{2} \mathrm{O}\right)_{2}\left(\mathrm{H}_{2} \mathrm{O}\right)_{4}\right] \cdot 2\left(\mathrm{C}_{14} \mathrm{H}_{9} \mathrm{O}_{4}\right)} \\
\mathrm{C}_{40} \mathrm{H}_{38} \mathrm{MgN}_{4} \mathrm{O}_{14}\end{array}$} & 1 & $129-220$ & 166 & $4 \mathrm{H}_{2} \mathrm{O}$ & 8.61 & 8.75 & & & & $\begin{array}{l}\text { bright } \\
\text { brown }\end{array}$ \\
\hline & 2 & $221-409$ & $298 ; 350$ & $2 \mathrm{C}_{13} \mathrm{H}_{9} \mathrm{O}_{2}$ & 47.11 & 47.92 & & & & \\
\hline \multirow[t]{2}{*}{823.06 g/mol } & 3 & $409-553$ & $431 ; 470 ; 527$ & $2 \mathrm{C}_{6} \mathrm{H}_{6} \mathrm{~N}_{2} \mathrm{O}$ & 28.91 & 29.65 & & & & \\
\hline & 4 & $557-952$ & $796 ; 867$ & $\mathrm{CO}_{2} ; \mathrm{CO}$ & 9.07 & 8.75 & 6.30 & 4.90 & $\mathrm{MgO}$ & black \\
\hline \multirow{2}{*}{$\begin{array}{l}{\left[\mathrm{Ca}\left(\mathrm{C}_{6} \mathrm{H}_{6} \mathrm{~N}_{2} \mathrm{O}\right)_{2}\left(\mathrm{C}_{14} \mathrm{H}_{9} \mathrm{O}_{4}\right)_{2}\left(\mathrm{H}_{2} \mathrm{O}\right)_{2}\right]} \\
\mathrm{C}_{40} \mathrm{H}_{34} \mathrm{CaN}_{4} \mathrm{O}_{2}\end{array}$} & 1 & $108-136$ & 130 & $2 \mathrm{H}_{2} \mathrm{O}$ & 4.02 & 4.48 & & & & $\begin{array}{l}\text { cream } \\
\text { colour }\end{array}$ \\
\hline & 2 & $189-306$ & $245 ; 286$ & $2 \mathrm{CONH}_{2} ; 2 \mathrm{COOH}$ & 21.77 & 22.17 & & & & \\
\hline \multirow{2}{*}{$802.81 \mathrm{~g} / \mathrm{mol}$} & 3 & $308-432$ & $328 ; 370 ; 411$ & $2 \mathrm{C}_{5} \mathrm{H}_{4} \mathrm{~N} ; 2 \mathrm{C}_{6} \mathrm{H}_{4}$ & 37.81 & 38.37 & & & & \\
\hline & 4 & $433-841$ & $567 ; 663 ; 713$ & $2 \mathrm{C}_{7} \mathrm{H}_{6} \mathrm{O}_{2} ; 2 \mathrm{C}_{7} \mathrm{H}_{6} \mathrm{O}$ & 28.16 & 27.90 & 8.24 & 6.99 & $\mathrm{CaO}$ & Black \\
\hline \multirow{2}{*}{$\begin{array}{l}{\left[\mathrm{Sr}\left(\mathrm{C}_{6} \mathrm{H}_{6} \mathrm{~N}_{2} \mathrm{O}\right)_{2}\left(\mathrm{C}_{14} \mathrm{H}_{9} \mathrm{O}_{4}\right)_{2}\left(\mathrm{H}_{2} \mathrm{O}\right)_{2}\right]} \\
\mathrm{C}_{40} \mathrm{H}_{34} \mathrm{~N}_{4} \mathrm{O}_{2} \mathrm{Sr}\end{array}$} & 1 & $171-226$ & 201 & $2 \mathrm{H}_{2} \mathrm{O}$ & 5.05 & 4.24 & & & & $\begin{array}{l}\text { light } \\
\text { brown }\end{array}$ \\
\hline & 2 & $261-370$ & 341 & $2 \mathrm{C}_{6} \mathrm{H}_{6} \mathrm{~N}_{2} \mathrm{O}$ & 29.01 & 28.70 & & & & \\
\hline \multirow{3}{*}{$850.35 \mathrm{~g} / \mathrm{mol}$} & 3 & $445-601$ & 558 & $2 \mathrm{C}_{7} \mathrm{H}_{5} \mathrm{O}_{2}$ & 27.68 & 28.46 & & & & \\
\hline & 4 & $624-850$ & 780 & $2 \mathrm{C}_{6} \mathrm{H}_{4}$ & 16.35 & 17.88 & & & & \\
\hline & 5 & $855-956$ & 905 & $\mathrm{CO}_{2} ; \mathrm{CO}$ & 7.95 & 8.47 & 13.96 & 12.19 & SrO & Black \\
\hline$\left[\mathrm{Ba}\left(\mathrm{C}_{6} \mathrm{H}_{6} \mathrm{~N}_{2} \mathrm{O}\right)_{2}\left(\mathrm{C}_{14} \mathrm{H}_{9} \mathrm{O}_{4}\right)_{2}\left(\mathrm{H}_{2} \mathrm{O}\right)_{2}\right]$ & 1 & $140-228$ & 208 & $2 \mathrm{H}_{2} \mathrm{O}$ & 4.35 & 4.00 & & & & brown \\
\hline $\mathrm{C}_{40} \mathrm{H}_{34} \mathrm{BaN}_{4} \mathrm{O}_{2}$ & 2 & $252-351$ & 313 & $2 \mathrm{C}_{6} \mathrm{H}_{6} \mathrm{~N}_{2} \mathrm{O}$ & 26.98 & 27.11 & & & & \\
\hline \multirow[t]{2}{*}{$900.06 \mathrm{~g} / \mathrm{mol}$} & 3 & $483-638$ & 576 & $2 \mathrm{C}_{7} \mathrm{H}_{5} \mathrm{O}_{2}$ & 26.12 & 26.89 & & & & \\
\hline & 4 & $648-938$ & $731 ; 815$ & $2 \mathrm{C}_{6} \mathrm{H}_{4} ; \mathrm{CO}_{2} ; \mathrm{CO}$ & 23.89 & 24.88 & 18.66 & 17.04 & $\mathrm{BaO}$ & black \\
\hline
\end{tabular}

\subsection{Description of crystal structure}

The molecular structure of complex I, with the atom numbering scheme, is shown in Fig. 3 and crystal structural properties are summarised in Table 4. The asymmetric unit of I contains one $\mathrm{Mg}(\mathrm{II})$ ion, one non-coordinated diphenic acid ligand, one nicotinamide ligand, and two aqua ligands. The $\mathrm{Mg}$ (II) ion is located on a centre of symmetry and coordinated by four oxygen atoms from aqua ligands and two nitrogen atoms from nicotinamide ligands, thus showing a distorted octahedral coordination geometry. The Mg-O bond lengths are 2.037(2) and 2.049(2) $\AA$, while the Mg-N bond length is $2.226(2) \AA$ (Table 5), respectively. Molecules of I are linked by $\mathrm{N}-\mathrm{H} \cdots \mathrm{O}, \mathrm{O}-\mathrm{H} \cdots \mathrm{O}$ and $\mathrm{C}-\mathrm{H} \cdots \mathrm{O}$ hydrogen bonds (Table 6). The amino N2 atom acts as a hydrogen-bond donor to atom $01^{\mathrm{ii}}$, so forming a centrosymmetric $\mathrm{R}_{2}{ }^{2}(8)$ ring, which is running parallel to the [110] direction [(ii) 2-x, 2-y, 1-z]. This 1D supramolecular network expands to the $2 \mathrm{D}$ supramolecular network with $\mathrm{O}-\mathrm{H} \cdots \mathrm{O}$ hydrogen bonds which are produce $\mathrm{R}_{2}{ }^{2}(8)$ and $\mathrm{R}_{6}{ }^{4}(16)$ rings formed between diphenic acid and aqua ligands (Fig. 4). Similarly, aqua 03 atom acts as a hydrogen-bond donor to atom $01^{\mathrm{iii}}$, so forming centrosymmetric $\mathrm{R}_{2}{ }^{2}(16)$ ring, which is running parallel to the [100] direction [(iii) 2-x, 1-y, 1-z]. The combination of $\mathrm{N}-\mathrm{H} \cdots \mathrm{O}$ and $0-\mathrm{H} \cdots 0$ hydrogen bonds produces edge-fused $\mathrm{R}_{2}{ }^{2}(8) \mathrm{R}_{2}{ }^{2}(16) \mathrm{R}_{4}{ }^{2}(20)$ rings which are running parallel to the $a b$ plane (Fig. 5). Also, the intermolecular $\pi \cdots \pi$ contacts occur between the pyridine and phenyl rings (Fig. 6 ). The perpendicular distance from pyridine and phenyl rings are 3.731 and $3.678 \AA$. The distances between the rings centroids are 3.737 (3) and 4.140 (3) $\AA$. All of these intermolecular interactions give 3D framework results. 
Table 4

Crystal data and structure refinement parameters for $\mathbf{I}$.

\begin{tabular}{|c|c|}
\hline Empirical formula & $\mathrm{C}_{40} \mathrm{H}_{38} \mathrm{~N}_{4} \mathrm{MgO}_{14}$ \\
\hline Formula weight & 823.05 \\
\hline Crystal system & Triclinic \\
\hline Space group & P-1 \\
\hline$a(\AA)$ & $8.336(5)$ \\
\hline$b(\AA)$ & $10.785(8)$ \\
\hline$c(\AA)$ & $11.516(8)$ \\
\hline$a\left({ }^{\circ}\right)$ & $78.05(2)$ \\
\hline$\beta(\rho)$ & $87.688(19)$ \\
\hline$\gamma(\Theta)$ & 78.217 (19) \\
\hline$V\left(\AA^{3}\right)$ & $991.6(12)$ \\
\hline Z & 1 \\
\hline$D_{\mathrm{c}}\left(\mathrm{g} \mathrm{cm}^{-3}\right)$ & 1.378 \\
\hline$\theta$ range $\left(^{\circ}\right)$ & $3.1-28.3$ \\
\hline$\mu\left(\mathrm{mm}^{-1}\right)$ & 0.12 \\
\hline Measured refls. & 36506 \\
\hline Independent refls. & 4885 \\
\hline$R_{\text {int }}$ & 0.039 \\
\hline$S$ & 1.09 \\
\hline R1/wR2 & $0.068 / 0.142$ \\
\hline$\Delta \rho_{\max } / \Delta \rho_{\min }\left(\mathrm{e}^{-3}\right)$ & $0.35 /-0.22$ \\
\hline
\end{tabular}

Table 5

Selected bond distances and angles for complex I ( $\AA$,

\begin{tabular}{|c|c|c|c|}
\hline Mg1-02 & $2.037(2)$ & Mg1-03 & $2.049(2)$ \\
\hline Mg1-N1 & $2.226(2)$ & & \\
\hline 02-Mg1-03i & 88.38(8) & 02-Mg1-03 & $91.62(8)$ \\
\hline O2-Mg1-N1 ${ }^{\mathrm{i}}$ & $90.61(9)$ & O2-Mg1-N1 & $89.39(9)$ \\
\hline O3-Mg1-N1 & 91.39(9) & O3-Mg1-N1 ${ }^{i}$ & $88.61(9)$ \\
\hline
\end{tabular}


Table 6

Hydrogen-bond parameters for complex I $\left(\AA,{ }^{\circ}\right)$

\begin{tabular}{|c|c|c|c|c|}
\hline $\mathrm{D}-\mathrm{H} \cdots \mathrm{A}$ & D-H & $\mathrm{H} \cdots \mathrm{A}$ & $D \cdots A$ & $D-H \cdots A$ \\
\hline $\mathrm{C} 5-\mathrm{H} 5 \cdots 05$ & 0.93 & 2.47 & 3.341 (3) & 155 \\
\hline $\mathrm{N} 2-\mathrm{H} 2 \mathrm{~A} \cdots \mathrm{O} 1^{\mathrm{ii}}$ & $0.86(3)$ & $2.11(3)$ & $2.970(3)$ & 177 \\
\hline $\mathrm{N} 2-\mathrm{H} 2 \mathrm{~B} \cdots 05$ & $0.85(3)$ & $2.43(3)$ & $3.187(3)$ & 148 \\
\hline $\mathrm{O} 3-\mathrm{H} 3 \mathrm{~A} \cdots \mathrm{O} 1^{\mathrm{iii}}$ & $0.79(4)$ & $1.98(4)$ & $2.735(3)$ & 160 \\
\hline $03-\mathrm{H} 3 \mathrm{~B} \cdots 05^{\mathrm{i}}$ & $0.86(4)$ & $1.83(4)$ & $2.695(3)$ & 179 \\
\hline $\mathrm{O} 2-\mathrm{H} 2 \mathrm{C} \cdots \mathrm{O} 4$ & $0.84(4)$ & $1.81(4)$ & 2.649 (3) & 177 \\
\hline $\mathrm{O} 2-\mathrm{H} 2 \mathrm{D} \cdots \mathrm{O} 6^{\mathrm{iv}}$ & $0.83(4)$ & $1.93(4)$ & $2.740(3)$ & 164 \\
\hline O7-H7A $\cdots 04$ & $0.93(4)$ & $1.63(4)$ & $2.552(3)$ & 178 \\
\hline
\end{tabular}

\section{Conclusions}

Mixed ligand complexes containing neutral nicotinamide and monoanionic diphenic acid ligands of the alkaline earth metal $\mathrm{Mg}^{2+}, \mathrm{Ca}^{2+}, \mathrm{Sr}^{2+}$ and $\mathrm{Ba}^{2+}$ cations were synthesised. The structural properties of the compound containing $\mathrm{Mg}^{2+}$ cation from the molecules obtained in crystalline form were elucidated using the single-crystal structure analysis. The coordination circumference of the $\mathrm{Mg}^{2+}$ metal cation is six, and two neutral nicotinamide and four aqua ligands were provided as coordination monodentate to the metal cation. The geometry of the coordination sphere is distorted octahedral. The 2 + charge valence of the coordination sphere is provided by two monoanionic diphenate ligands located outside of the sphere as counter-ion. Structural details of other metal cation complexes, which could not be obtained as a single crystal, which would allow the analysis of the crystal structure, were tried to be elucidated by chemical composition analysis, spectroscopic and thermal analysis methods. According to spectroscopic and thermal analysis data, it is thought that the coordination circles of the metal cations in the structures proposed to be iso-structures are octal, and this coordination is provided by two neutral nicotinamide, two aqua and two monoanionic-bidentate diphenate ligands from one carboxylate group. The results obtained from thermal degradation analysis curves and spectroscopic analysis data of the complexes support these claims. Thermal analysis of the molecules has been shown by powder XRD analysis, where the relevant metal oxide compounds are formed as final decomposition products. The proposed structure formulas according to the chemical composition analysis of the compounds that cannot be analysed for single-crystal structure are considered as in Fig. 6 .

\section{Declarations}

\section{Acknowledgements}

This study was financially supported by Sinop University (Project No. SÜB-1901-18-01) and Hitit University (FEF19004.18.001) in Turkey. The authors acknowledge to Scientific and Technological Research Application and Research Center, Sinop University, Turkey, for the use of the Bruker D8 QUEST diffractometer.

\section{Funding}

This study was financially supported by Sinop University (Project No. SÜB-1901-18-01) and Hitit University (FEF19004.18.001) in Turkey.

\section{Conflicts of interest/Competing interests}

There is no conflict of interest with any person or institution related to the work carried out.

"The authors declare that they have no known competing financial interests or personal relationships that could have appeared to influence the work reported in this paper."

\section{Availability of data and material}

There is no data or material available in addition to the presented article work. All study results are given in the presented study. All data and materials presented are available.

\section{Code availability}

Crystal data number, CCDC number 2035106

\section{Authors' contributions}

Ömer Yurdakul: Conceptualisation Methodology (\%20). 
Dursun Ali Köse: Methodology, Software, Visualization, Investigation, Resources, Project administration (\%40).

Zarife Sibel Şahin: Investigation, Visualization (\%20).

Onur Şahin: Writing - review \& editing, Project administration (\%20).

Additional declarations for articles in life science journals that report the results of studies involving humans and/or animals

Not applicable

Ethics approval (include appropriate approvals or waivers)

Not applicable

Consent to participate (include appropriate statements)

Not applicable

Consent for publication (include appropriate statements)

On behalf of all authors, the corresponding author has given permission for the relevant article.

\section{References}

1. L.J. Murray, M. Dinca, J.R. Long, Chem. Soc. Rev. 38, 1294 (2009)

2. Q. Chen, Z. Chang, W. Song, H. Song, H. Song, T. Hu, X. Bu, Angew. Chem. Int. Ed. 52, 11550 (2013)

3. Ö Yurdakul, Z.S. Şahin, D.A. Köse, O. Şahin, F. Akkurt, J. Mol. Struct. 1218, 128514 (2020)

4. M. Plabst, L.B. McCusker, T. Bein, J. Am. Chem. Soc. 131, 18112 (2009)

5. Y. Liu, V.C. Kravtsov, M. Eddaoudi, Angew. Chem. Int. Ed. 47, 8446 (2008)

6. M.H. Alkordi, J.A. Brant, L. Wojtas, V.C. Kravtsov, A.J. Cairns, M. Eddaoudi, J. Am. Chem. Soc. 131, 17753 (2009)

7. G. Wang, L. Yang, Y. Li, H. Song, W. Ruan, Z. Chang, X. Bu, Dalton Trans. 42, 12865 (2013)

8. J.Y. Lee, O.K. Farha, J. Roberts, K.A. Scheidt, S.T. Nguyen, J.T. Hupp, Chem. Soc. Rev. 38, 1450 (2009)

9. L. Ma, C. Abney, W. Lin, Chem. Soc. Rev. 38, 1248 (2009)

10. J.R. Li, R.J. Kuppler, H.C. Zhou, Chem. Soc. Rev. 38, 1477 (2009)

11. J. Tao, J.X. Shi, M.L. Tong, X.X. Zhang, X.M. Chen, Inorg. Chem. 40, 6328 (2001)

12. S. Zang, Y. Su, Y. Li, Z. Ni, Q. Meng, Inorg. Chem. 45, 174 (2006)

13. K. Biradha, M. Sarkar, L. Rajput, Chem. Commun. 40, 4169 (2006)

14. S.R. Batten, R. Robson, Angew. Chem. Int. Ed. 37, 1460 (1998)

15. D. Venkataraman, G.B. Gardner, S. Lee, J.S. Moore, J. Am. Chem. Soc. 117, 11600 (1995)

16. C. Janiak, Dalton Trans. 14, 2781 (2003)

17. B. Moulton, M.J. Zaworotko, Chem. Rev. 101, 1629 (2001)

18. E.A. Tomic, J. Appl. Polym. Sci. 9, 3745 (1965)

19. J.R. Li, R.J. Kuppler, H.C. Zhou, Chem. Soc. Rev. 38, 1477 (2009)

20. R. West, J. Am. Chem. Soc. 85, 2589 (1963)

21. J.A.J. Jarvis, Acta Crystallogr 15, 964 (1962)

22. C.M. a), Grammaccioli, R.E. Marsh, Acta Crystallogr. 21, 594 (1966). b) C.M. Grammacioli, Acta Crystallogr. 21, 600 (1966)

23. K. Okada, M.I. Kay, D.T. Cromer, I. Almodovar, J. Chem. Phys. 44, 1648 (1966)

24. A. a), E. Weiss, I. Riegler, Alt, H. Bohme, Z. Naturforsch. B: Anorg. Chem. Org. Chem. 41, 18 (1986). b) A. Weiss, E. Riegler, C. Robl, Z. Naturforsch. B: Anorg. Chem. Org. Chem. 41, 1329 (1986). c) A. Weiss, E. Riegler, C. Robl, Z. Naturforsch. B: Anorg. Chem. Org. Chem. 41, 1333 (1986). d) A. Weiss, C. Robl, Z. Naturforsch. B: Anorg. Chem. Org. Chem. 41, 1341 (1986). e) A. Weiss, C. Robl, Z. Naturforsch. B: Anorg. Chem. Org.Chem. 41,1485 (1986). f) A. Weiss, C. Robl, Z. Naturforsch. B: Anorg. Chem. Org. Chem. 41, 1490 (1986)

25. C. a), Robl, A. Weiss, Mater. Res. Bull. 22, 373 (1987). b) C. Robl, A. Weiss, Z. Anorg. Allg. Chem. 546, 161 (1987). c) C. Robl, V. Gnutzmann, A. Weiss, Z. Anorg. Allg. Chem. 549, 187 (1987)

26. A. a) Weiss andC. Z. Robl, B. Naturforsch: Anorg. Chem. Org. Chem. 41, 1337 (1986). b) A. Weiss, C. Robl, Z. Naturforsch. B: Anorg. Chem. Org. Chem. 41, 1495 (1986). c) A. Weiss, E. Riegler, C. Robl, Z. Naturforsch. B: Anorg. Chem. Org. Chem. 41, 1501 (1986)

27. C. a), Robl, A. Weiss, Mater. Res. Bull. 22, 497 (1987. b) C. Robl, A. Weiss, Z. Anorg. Allg. Chem. 546, 152 (1987)

28. H. Li, M. Eddaoudi, M. O’Keeffe, O.M. Yaghi, Nature 402, 276 (1999)

29. M. Eddaoudi, J. Kim, N. Rosi, D. Vodak, J. Wachter, M. O’Keeffe, O.M. Yaghi, Science 295, 469 (2002)

Page $9 / 12$ 
30. S. Noro, R. Kitaura, M. Kondo, S. Kitagawa, T. Ishii, H. Matsuzaka, M. Yamashita, J. Am. Chem. Soc. 124, 2568 (2002)

31. K. Seki, S. Takamizawa, W. Mori, Chem. Lett. 30, 332 (2001)

32. H.K. Chae, D.Y. Siberio-P'erez, J. Kim, Y. Go, M. Eddaoudi, A.J. Matzger, M. O’Keefe, O.M. Yaghi, Nature 427, 523 (2004)

33. D.N. Dybtsev, H. Chun, K. Kim, Angew. Chem. Int. Ed. 43, 5033 (2004)

34. G. F'erey, C. Serre, C. Mellot-Draznieks, F. Millange, S. Surbl’e, J. Dutour, I. Margiolaki, Angew. Chem. Int. Ed. 43, 6296 (2004)

35. J. Yang, J.F. Ma, Y.Y. Lui, J.C. Ma, S.R. Batten, Cryst. Growth Des. 9(4), 1894 (2009)

36. R. Wang, Y. Zhou, Y. Sun, D. Yuan, L. Han, B. Lou, B. Wu, M. Hong, Cryst. Growth Des. 5(1), 251 (2005)

37. P.D.C. Dietzel, R. Blom, H. Fjellvåg, Dalton Trans. 4, 586 (2006)

38. I.L. Malaestean, M. Speldrich, S.G. Baca, A. Ellern, H. Schilder, P. Kögerler, Eur. J. Inorg. Chem. 8, 1011 (2009)

39. L. Gou, B. Zhang, H. Hu, X. Chen, B. Wang, Q. Wu, T. Qin, Z. Tang, J. Mol. Struct. 889(1-3), 244 (2008)

40. L. Gou, L. Li, J. Li, X. Fan, D. Li, Z. Anorg. Allg. Chem. 636, 1591 (2010)

41. F. Lian, R. Wang, L. Han, F. Jiang, M. Hong, Z. Anorg. Allg. Chem. 631, 2485 (2005)

42. L.E. Weingartz, C.Y. Wang, R.L. LaDuca, Inorganica Chem. Acta 421, 500 (2014)

43. B.L. Martinez, A.D. Shrode, R.J. Staples, R.L. LaDuca, Polyhedron 151, 369 (2018)

44. Z.S. Şahin, O. Şahin, Ö Dağlı, D.A. Köse, Polyhedron 117, 214 (2016)

45. G.M. Sheldrick, Acta Crystallogr. Sec. A 64, 112 (2008)

46. G.M. Sheldrick, Acta Crystallographica C 71, 3 (2015)

47. Bruker-AXS,. Bruker, APEX2, SAINT and SADABS (AXS Inc., Madison, Wisconsin, USA, 2013)

48. C.F. Macrae, I.J. Bruno, J.A. Chisholm, P.R. Edgington, P. McCabe, E. Pidcock, L. Rodriguez-Monge, R. Taylor, J. van de Streek, P.A. Wood, J. Appl. Cryst. 41(2), 466 (2008)

49. L.J. Farrugia, WinGX and ORTEP for Windows: an update. J. Appl. Cryst. 45, 849 (2012)

50. Ö Dağlı, D.A. Köse, G.A. Avcı, O. Şahin, J. Therm. Anal. Calorim. 129(3), 1389 (2017)

51. Ö Dağlı, D.A. Köse, O. İçten, G.A. Avcl, O. Şahin, J. Therm. Anal. Calorim. 136(4), 1467 (2019)

52. Ö Yurdakul, D.A. Köse, Hittite J. Sci. Eng. 1(1), 51 (2014)

\section{Figures}

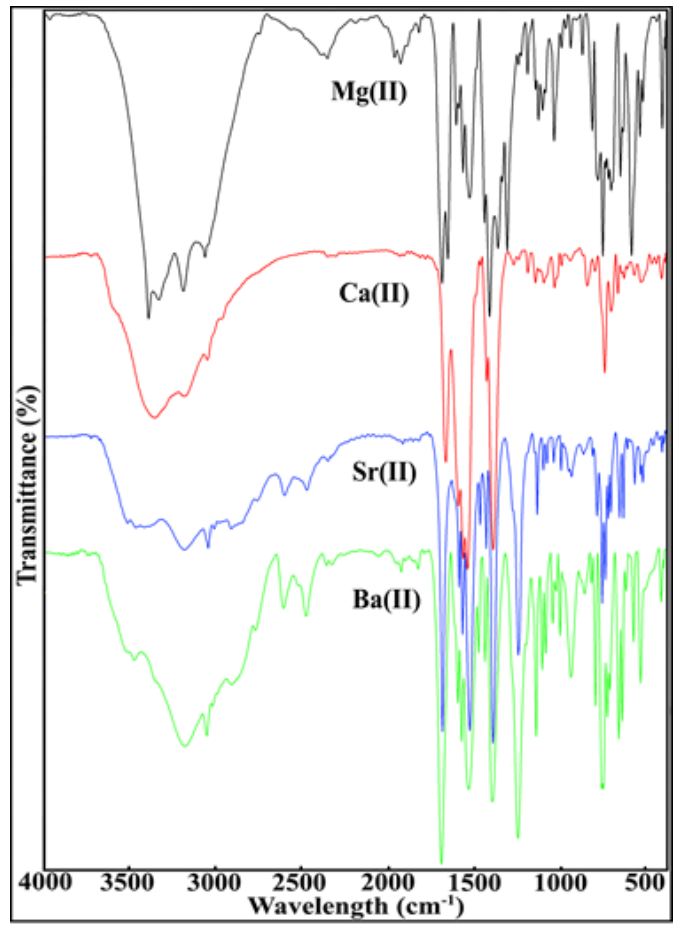

Figure 1

FT-IR spectra of alkaline earth metal cation complexes. 

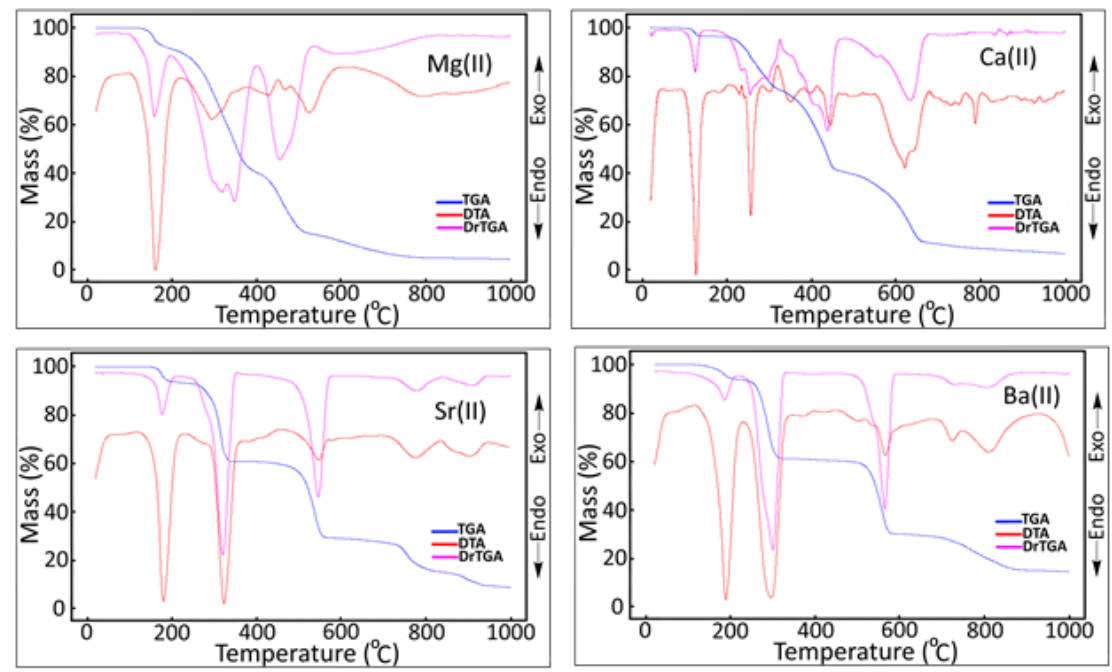

\section{Figure 2}

Thermal analysis curves of alkaline earth metal cation complexes.

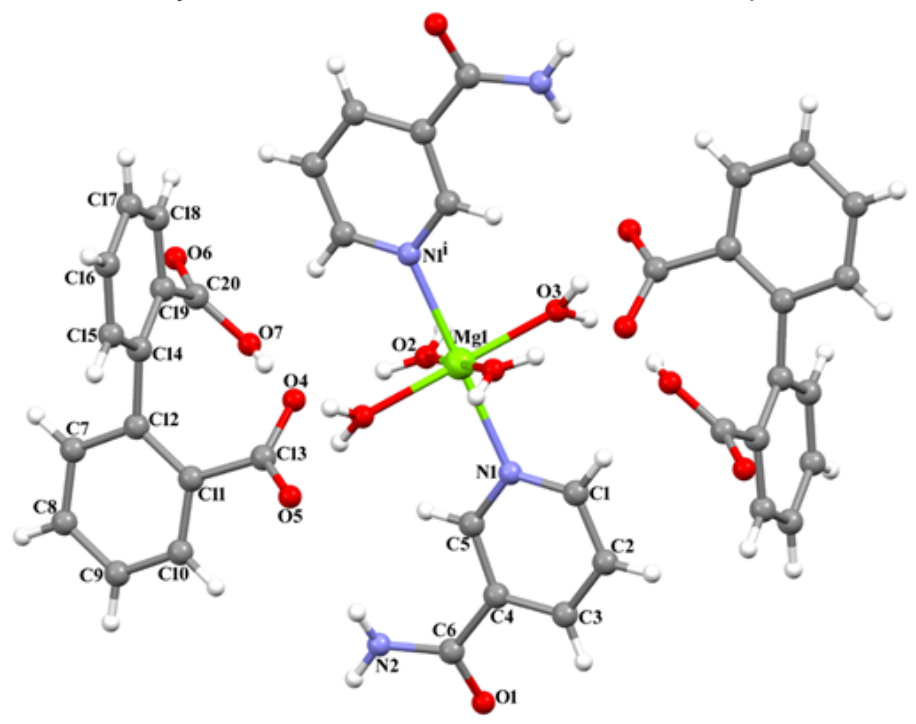

Figure 3

The molecular structure of complex I, showing the atom numbering scheme. [(i) 1-x, 1-y, 1-z]

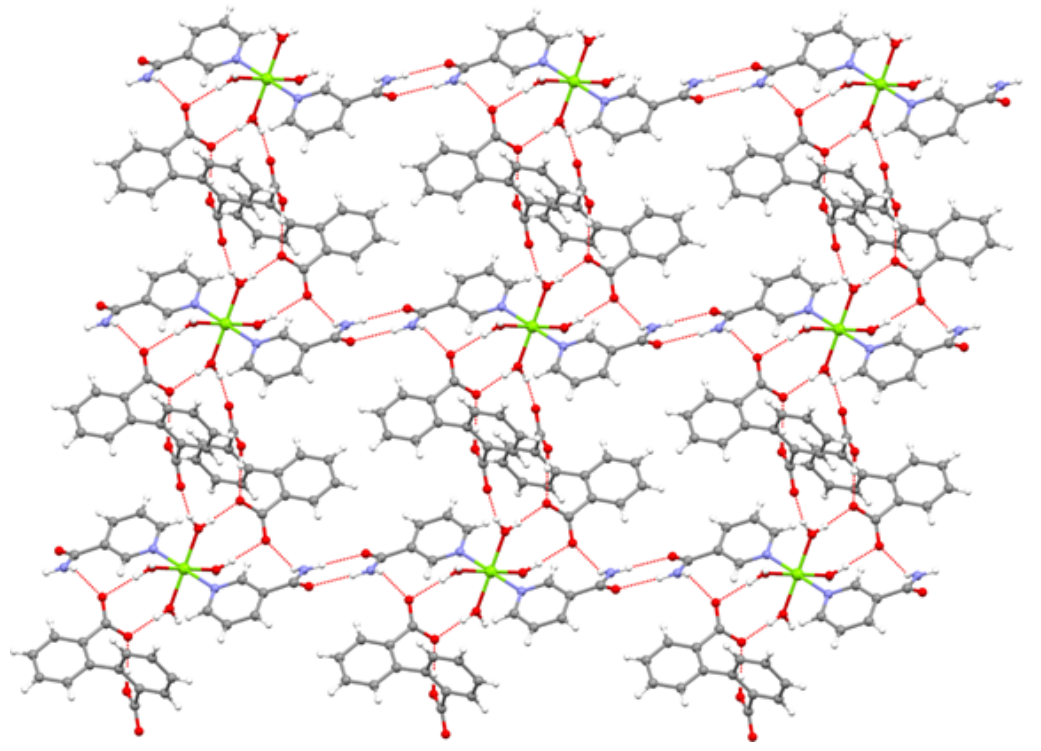

Figure 4 
The 2D supramolecular network in I.

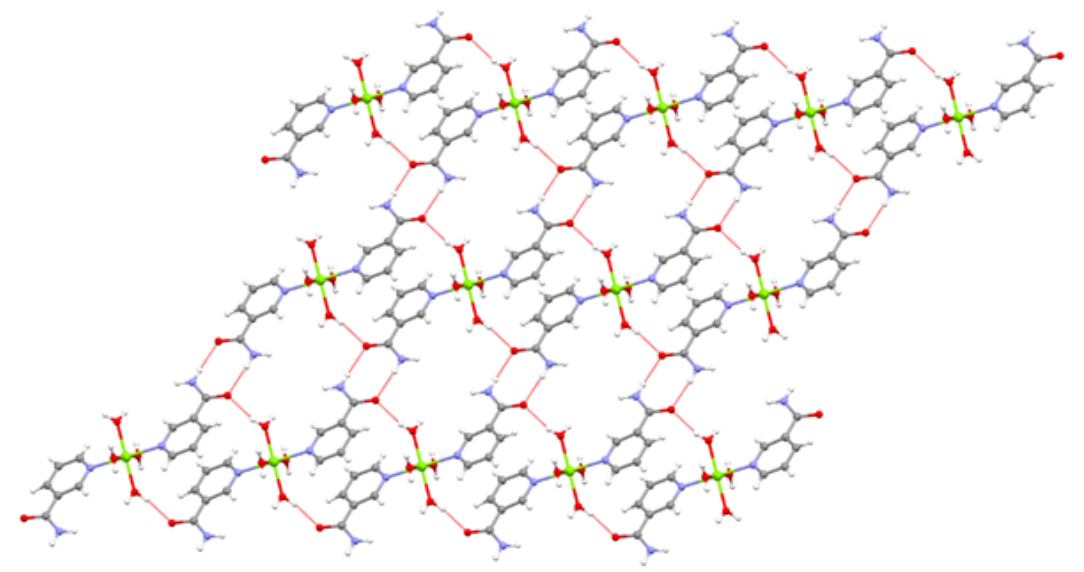

Figure 5

The formation of edge-fused R22(8)R22(16)R42(20) rings in I.

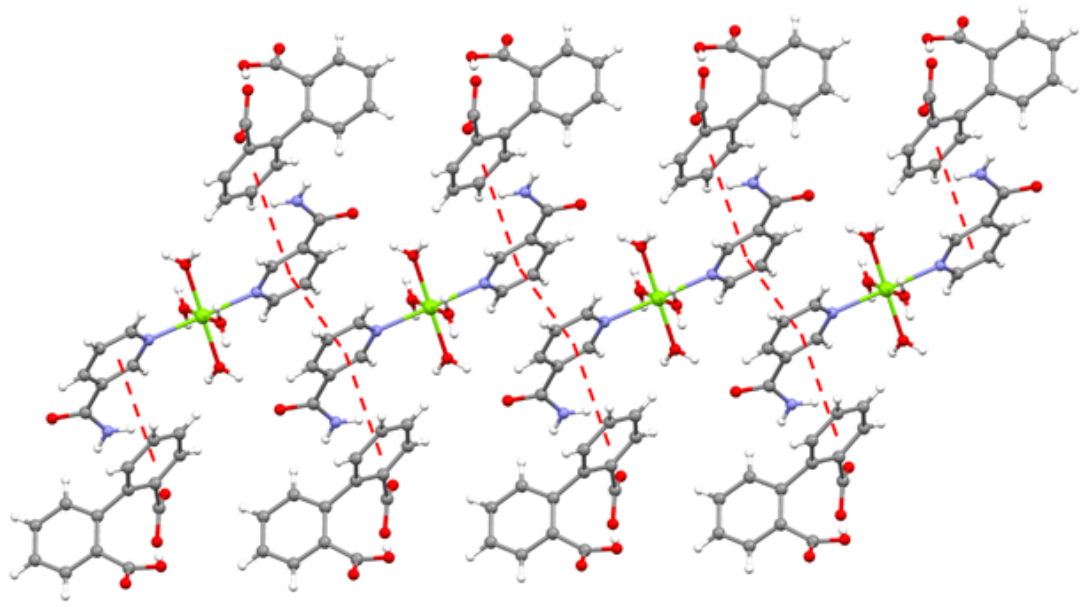

\section{Figure 6}

The $\pi \cdots \pi$ interactions in I.

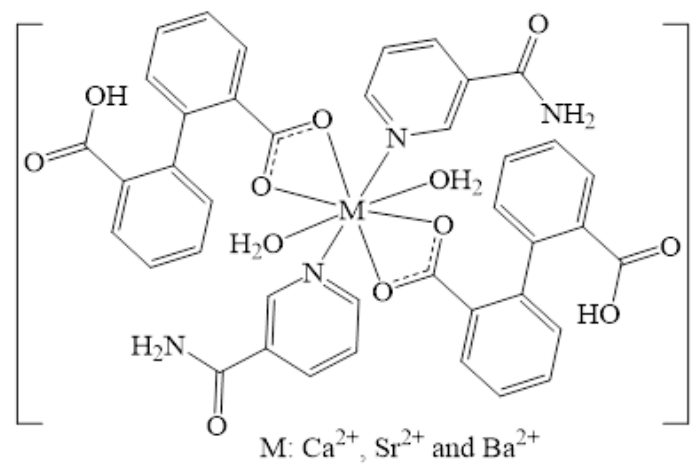

Figure 7

Proposed structural formula for $\mathrm{Ca} 2+, \mathrm{Sr} 2+$ ve $\mathrm{Ba} 2+$ complexes 